\title{
Helen Salisbury: Battening down the hatches for a second wave
}

\author{
Helen Salisbury GP
}

Oxford

Autonomy is one of the four pillars of Western medical ethics. People have a right to make their own decisions about what treatment to accept, as long as they have capacity to do so. ${ }^{1} \mathrm{My}$ patients can-and often do-stop taking the tablets I prescribe for their diabetes or hypertension, refuse surgery that could be curative, and ignore advice about alcohol, exercise, or smoking. It's my job to provide-accurately, clearly, and to the best of my knowledge- the information on which to base their decisions, and it's their right to ignore it.

Infectious diseases are an exception to the rules on autonomy. While you're at liberty to damage your own health, you can still be prevented from harming others. The Public Health Act 1984 and the new Health Protection (Coronavirus) Regulations 2020 enable enforcement of rules to prevent the spread of infection. ${ }^{2}$ Enforcement is, of course, a last resort and not an efficient way of changing behaviour. If people know the rules and understand the reasons, most are likely to comply, as we saw at the start of lockdown. Clear messaging around those rules, plus a combination of fear, altruism, and a generally law abiding public, meant that most people stayed at home.

Now the picture is less clear. Nobody knows what the rules are. We should not go to work-unless we have to; we should be socially distanced at work-unless that's not possible. We can have other people in our houses (nannies and cleaners), but we can't invite the people we most want to see. There is little sense or consistency, and the rules seem to be more about economic activity than infection control. As always, the people with lowest incomes have the fewest choices, being forced to use public transport where two metre separation is impossible, to return to working conditions that may be similarly unsafe.

If, aside from being in a constant and uncomfortable state of alertness, people are unsure what the rules are, we can't expect them to comply. Perhaps we just need to trust them to act sensibly_but how can people make sensible decisions without accurate information about risk? We know how many have died in hospitals and care homes from infections contracted weeks ago, but we have little clue as to the level of circulating virus in the local population.

The final missing ingredient is trust: a government that has counted single gloves as an item of PPE, classifies kits in the post as tests performed, and counts two different specimens from the same patient as two tests ${ }^{3}$ has lost the trust of the medical profession and the wider public. Our politicians have not only mishandled numbers but also shown world beating incompetence in their response to the pandemic. ${ }^{4}$ The test, track, and trace system we needed two months ago is still not operational. We'd better batten down the hatches for the second wave.

Competing interests: See www.bmj.com/about-bmj/freelance-contributors.

Provenance and peer review: Commissioned; not externally peer reviewed.

1 General Medical Council. Consent: patients and doctors making decisions together. https: /www.gmc-uk org/ethical-guidance/ethical-guidance-for-doctors/consent/part-1-principles. Griffith R. Using public health law to contain the spread of COVID-19. Br J Nurs Griffith R. Using public health law to contain the spread of COVID-19. Br J Nurs
2020;29:326-7. https://www.magonlinelibrary.com/doi/full/10.12968/bjon.2020.29.5.326. 10.12968/bjon.2020.29.5.326 32167816

3 Boycott-Owen M, Nuki P. Tens of thousands of coronavirus tests have been double-counted, officials admit. Telegraph 2020 May 21. https://www.telegraph.co.uk/ global-health/science-and-disease/tens-thousands-coronavirus-tests-have-double-countedofficials/.

4 Scally G, Jacobson B, Abbasi K. The UK's public health response to covid-19. BMJ 2020;369:m1932. 10.1136/bmj.m1932 32414712

Published by the BMJ Publishing Group Limited. For permission to use (where not already granted under a licence) please go to http://group.bmj.com/group/rights-licensing/ permissions 